\title{
Family Institution and Modernization: A Sociological Perspective
}

\author{
ILORI OLADAPO MAYOWA. \\ DEPARTMENT OF SOCIOLOGY, FACULTY OF THE SOCIAL SCIENCES, EKITI STATE UNIVERSITY, \\ ADO EKITI.
}

\begin{abstract}
Family is the basic unit of a society which is saddled with biological functions such as reproduction, social functions pertaining to nurturing and socialisation of children. Before modernization, families usually consist of several generations and branches of extended family living in the same village. As modernization occurs, young people tend to move away from the village in which they were raised in search of jobs, leaving the older generations behind, they relocate to cities and meet people they probably never would have met had stayed home. The overall effects of modernization on family institution cannot be under-estimated. Modernization is seen to be changing the face of the family structure. The traditional African family which is known to be agrarian, polygamous and extended has undergone changes where nuclear and asymmetrical types have emerged; family support for the elderly is affected by the changes in the family formation, family dynamics, as well as people's value and their way of life. High degree of physical mobility associated with new job opportunities at urban centres has loosen the phenomenon of face to face relationships and eroded the strength of the family. This study therefore looked at the overall effects of modernization on the traditional African family structure. Data for this study was sourced mainly from the secondary data and other literature on the subject under study.
\end{abstract}

Keywords: Family, modernization, industrialization, nuclear, extended

DOI: $10.7176 /$ RHSS/9-8-14

Publication date: April $30^{\text {th }} 2019$

\section{INTRODUCTION}

A generation ago, many people, sociologists included, viewed with alarm the changes in the family that seemed to accompany the industrialization of society. The common of this bleak outlook was to predict the decline of the family as a consequence of a decline of its social functions. One influential formulation of this was that the family was passing from institution to companionship. The agrarian family was the necessarily the centre of life for the individual, it possessed major economic functions, for the agrarian family was a productive unit, organized by a division of labour to operate a farm. Except for a few who went into religious institutions or into the cities, individuals were tied into the family status and their economic roles were found in the family as a work group. Modernization has increased urbanization in present time, the rural family develops more and more towards centrifugal tendencies, its economic homogeneity based upon a single cumulative economic activity of its members, declines, joint family property tends to be disrupted since its individuals adult members being increasingly engaged in different occupations, because of this reason, they are unable to reside together (Chaudhry, 2004). Modernization has altered the family by adapting it from a unit of production into a unit of consumption, producing a decline in potency and a revolution in the relationship between couples and between maternities and children.

In preindustrial societies, the family performed many functions that have since become community of societal responsibilities, it not only socialised the young, it provided much other training of the child as well. Among the European peasants and even later even later among American farmers, a boy learned his occupation by working with his father at a young age. Furthermore, in an agrarian society, the kinship group maintained the aged, nursed the sick, buried the dead, and provided for the mentally ill of physically crippled. It also ensured support for widows and orphans and made a place for the occasionally unmarried woman. As a result, one can understand how kinship became a most binding and obligatory relationship regardless of personal feelings, requiring that family interest takes precedence over individual ones. The individuals were locked into a demanding structure of kinship obligation and duties that extended beyond the nuclear family to a wider network to kin. When the work place was removed from the household, and economy separated from family a revolution in family life was underway. As in revolution, an old way of life was destroyed, a new way of life emerged. The old order of family, a productive and reproductive unit tied closely to the community and in turn building the dependent individuals to it, eroded. In its place, a new form of family life emerged; the modern nuclear family. Anthony Giddens (1997) 
distinguished three main types of pre-modern society, hunting and gathering societies, pastoral and agrarian societies, and non-industrial civilizations. Arensberg and Kimball's well known study of Irish farmers, entitled "family and community in Ireland" described the traditional Irish farming as a patriarchal extended family. Such families emphasized the absolutely authority of men because property was passed down through the male line. On the farm, the father-son relationship was also that of owner-employee (Arensberg \& Kimball).

The new family lacked the dominant economic and social functions that gave stability and authority to the premodern family. It could not transmit occupational succession to its children, especially in the case of wage-earning working class and the salaried clerks and professionals. It could no longer adequately educate its children within the family only, and needed to send them to school, nor did it need children for economic reasons. And with loss of authority and loss of function came a decline in an extended family network. Increasingly, family came to mean father, mother and the children in a separate house-hold; the nuclear family. The revolutionary shaping of the modern nuclear family was accompanied by a revolution in sexual attitudes and practices. Young people began to give more attention to their own feelings less parental wishes and the needs of property, they began to court whom they like rather than whom their parents thought best.

The revolution shaping of the modern nuclear family was accompanied by a revolution in sexual attitude and practices. Young people began to give more attention to their own feelings less to parental wishes. There was also an increase in the premarital sex. This allows people to make their own marital choices, free from both parental approval and concern about keeping property in the family. People no longer had to delay marriageable age until their parents died or retired, nor did property concerns any longer dominate the choice of a spouse. As these matters became less important, other concern emerges, men and women began to select their marriage partners, they began to seek people who appealed to them, and romantic attraction rapidly became the basis for marriage, "I love you" became the precondition for asking "will you marry me". A new freedom of personal choice for romantic love and also sexual intimacy had now entered society, the individualism which capitalism had created permeated all sphere of social life, not just the economy; it shaped the intimate and private sphere of life as well as the public.

Just as capitalism separated the economy from the family, it also forcefully freed people from land and traditional modes of agricultural life, it gave them no choice but to seek work as employed labour, and it required they be aggressively individualistic in looking out for themselves. When the new working class internalized in looking the sentiments of individual's interest, this new egoism learned in the market soon undercut its obligations to community and the ties to family and lineage. For the developing capitalist class, property was still significantly tied to the family and its rights of inheritance, so the family remained firmly in control of individuals. But the working class had no property to preserve, no family business to transmit, and so they were free to pursue individual rather than family objectives once the idea of doing so has occurred to them.

The realm of freedom available to the individuals under capitalism nonetheless remained limited, particularly for those who did not own property. Yet the separation of family from economy and the loosening of community control had given to common people the idea of a personal life free from economic and political domination. The realm of family life, separated from economic production, came to be identified with such a personal life, one in which love and personal happiness were possible. The difference between traditional and modern family forms has often been described in terms of losses of function for the extended kin group. The nuclear family in a modern society in much less powerful and versatile than was the traditional extended family. Tasks once assumed by extended kin are now performed by outside agencies. The industrial revolution dramatically changed the relationship between home and the workplace, and consequently, the relationship among the family members. Women and children lost their economic value and became dependent upon the earning of the husband. The modern family is now primarily a consuming unit highly depended on the economic system beyond the home over which the family members have little control.

In the political sphere, the rise of the modern centralised state has reduced the need for protection once provided by extended kin. Armies, police and courts had replaced relatives. The public school system has been created to educate people for work in an industrial economy. Religious needs are also increasingly met by specialists' one side the family setting and family functions become narrower. As the extended family become less and less important as a source of goods and services, the young are freed from control by their elders. At the same time, the challenges of modern life create a need for affection and emotional support that cannot easily be met by family members with whom one has relationships of unequal power and rivalry. 


\section{LITERATURE REVIEW}

Edward Shorter (2000) in "The Making of the Modern Family" asserted that courtship was based on instrumental consideration: that the relationship between spouse were mainly contractual, with male peasants caring more for their animals than they did for their wives, that mothers were indifferent about their children's welfare, and the community constantly interfered with family privacy, inhibiting the chances of loving interaction between family members. Shorter (2000) argued further that the emergency of capitalism broke the bounds, local economy and hence freed family and communities' life from traditional constraints. Shorter was of the opinion that the relationship between husband and wife in the industrial societies is based on an agreement that is not emotionally bounded like in the pre-industrial societies when the parents choose love partner for their children. He also believed that in the industrial societies, husbands care less about their wives and care more about their business outfit. Women in the industrial societies according to Shorter were very indifferent about their children caring instead they concentrated on their various workplaces. Shorter then went further to say that the advent of industrialization has separated the family from the economic gains rather than emotional gains. Shorter submitted that capitalism forced people from land and traditional modes of agricultural life. It gave them no choice but to seek work as employed labour and it required they be aggressively individualistic in looking for themselves.

William Goode (1963) in "World Revolution and Family Patterns" used data from many different countries to try to isolate trends which he viewed as universal. Industrialization seems usually to be accompanied by a trend towards a "Conjugal Family System" relatively isolated nuclear families which retain links to grandparents and grandchildren and wives. The development of free labour markets he suggested made it possible for individuals to earn their living without the consent or cooperation of their kin. In Goode's analysis, industrial capitalism resulted in greater individual freedom: by which he means primarily freedom from the authority of parents or more inclusive kin groups. William Goode from the above study believed that industrialization served as catalyst to a modern nuclear family which does not recognise the grandparents and the grandchildren. He argued further that industrialization and/or capitalism made it possible for individual to earn their living without consulting their various kin and this means survival of the fittest was the order of the day in such societies. He submitted that ideological changes in values are helping to transform family systems and that these changes may precede or develop simultaneously with the coming of industrialization. He suggested that in all family system, there are some points of strain and that these points of strain make them vulnerable to change. Women and young in the traditional extended family subordinate to males and the young (as well as among intellectuals) "radical" new ideologies find especially fertile ground. Goode was of the opinion that in the pre-industrial societies, there was complete obedience between and among the family members and that the size of the family was very large which included, the extended kin and that economic production was not separated from the family. He said further that children (son especially) learnt their future occupation from their fathers and that after the death of their father, sons usually inherits their father's land. According to Goode, industrialization has brought a reduction in the family size- the modern nuclear family. He believed that industrialization had separated family from the economic unit and this had made individuals to seek their living from outside the family through a wage earning jobs and other remunerative employment, as a result of this much work was done in the factions and made individual to spend more time in the work place and less time with the family.

Edwin Shorter (2000) submitted that in the traditional family, members of the family felt they have more in common with various peer groups than with one another. In other words, the traditional family was much more a productive and reproductive unit. He was of the opinion that modernization radically changed the condition of life, giving people the opportunity to seek individual happiness. He believed that industrialization freed individuals from depending on inheritance for their livelihoods, elder sons no longer has to wait for their father's land, daughters no longer has to wait for a husband with land. Both sons and daughters could seek wage paying work, especially in the rapidly expanding urban industries; young people were heading off to the cities in droves for a white collar job.

Morris Zelditch (2005) observed that, extended family may decline significantly, even where industrialization does not occur. He suggested that apparently, any kind of non-subsistence expanding economy or even political changes can destroy the authority structure on which the descent group and family depend. He pointed to four basic conditions that can produce such a decline:

(a)Kinship and occupational structures become differentiated so that one's occupation may be very different from those of other family members.

(b)Income and status come to depend on factors that are not controlled by the extended family's land or business to be able to make his own living. 
(c)Sons begin to contribute more status and income to their families than to their fathers

(d)The self-interests of family members are not identified until the continuity of the family.

Morris Zelditch was of the view that industrialization alone was not the course of declining family functions. He believed that even in the absence of industrialization, there will be factors which will lead to declining family function. According to him, economic growth and economic development as well as increase in the complexity of political institution can lead to changes in the family institution.

Young and Willmott (2010) posited that kinship networks constituted an important basis for community solidarity and sociability. The relocation of many working class families in new town or over spill estates gave opportunity to consider the effects of geographical mobility on patterns of kinship behaviour. Young and Willmott viewed that geographical mobility attenuates kinship ties, since people were relocated as nuclear family ties, leaving most of their kin behind, mobility did indeed herald a reduction in interaction with him, women seemed to experience particularly keenly the relative isolation from their mothers and sisters, although some husbands could manage visits to kinfolk on their way to or from work. Young and Willmott viewed declining family structure in different perspective from other scholars, they viewed declining family interaction and function as a result of geographical mobility and migration. They also argued that mobility tends to reduce the family size thereby leading to a conjugal family system which is relatively small and the end product of this is relatively decline in the interaction of the family. Also in the "Symmetrical Family" by Young and Willmott (2004) posited that in the pre-industrial societies, the family was stable, it was centred on production and the family members were linked by economic necessity, by virtue of its control over production, the father was undisputed master of the house hold. They also believed that family in the industrialization era was characterised as a stage of disruption, when the process of industrialization threaten to tear the family apart. As home and work place were separated and family members became individual wage labourers, the interaction between them was correspondingly less intense. Fathers were often absent from the family, driven out by overcrowding and forced out to work. Mothers assumed the burden of care and emotional support for the family as a whole, as well as responsibilities for stretching the often meagre wages, the difficulties entailed in mothers' lot driven women in urban centres to seek the aid of female kinsfolk, thus giving use to new types of kinship networks from which men were by and large excluded.

In "Coal in our Life" by Dennis Henriques and Slaughter (1956), the relationship between spouses was described as highly contractual, that is both husbands and wives had certain fixed and non-negotiable obligations and being a good husband or a good wife consisted almost entirely in fulfilling these contractual duties. Husbands were expected to provide their families by giving a certain fixed proportion of their weekly pay packet to the wife as housekeeping money: her wages. Beyond that, it appears that little was expected of the housekeeping money and their own labour and ingenuity to provide a comfortable and harmonious home for husbands to seek refreshment in after a hard day at work. The wife's life, her schedule was almost entirely dictated by the timing of the husband's commitments, whatever shift he was on, whatever time he returns home, she was expected to be wait of clothes. Husbands spend most of their free time outside home, at sports events or clubs with their male friends and work mates. Their commitment and loyalty to their work mates are portrayed as deep and overriding most other commitments, it seemed partly form the experience of growing up together in the same community and partly from their shaving of the arduous work of mining in which not only the size of a man's pay pocket but his very life might depend on the quick-wittedness and energy of the members of his work team. Dennis Henriques and Slaughter were of the view that the relationship between husbands and wives was based on contract rather than on emotional. They argued further that the husband's workplace that determines the wife's schedules and that it is the husband that is responsible for giving the wife money that will be used to take care of the house and this money has now turned to wages for her. They also believed that husband spends more time playing with his friends in the clubs than playing with the wife at home and this makes the level of interact ion between spouses to less than the interaction between husbands and his work places.

Perlmam (2008) believed that industrialization has changed the sexual regulation functions of the family, thereby leading to its decline. He posited that virgin marriage has become relatively uncommon and may virtually disappear in the nearest future. Whether this is a "sexual revolution" (Skolnik,2000) or whether it is only another many historical swings between permissiveness and restrictiveness (Shorter,2007).

Mirowsky (2000) argued that in contemporary America, education and paid employment enhance women's bargaining power before and during marriage and there was much evidence to suggest that shared marital power is associated with emotional wellbeing for both spouses. He was of the view that need for a literate population for new kinds of occupational training as well as more advanced education led to the emergence of a mass educational 
structure separate from the family. He believed that modernization has brought an egalitarian family, that is to say, equal rights in the family's decision making process.

Anthony Giddens (2001) while speaking about the bearings of industry and modernization on the family system advocates that the structure of the family, the forms of interrelationship within the family are greatly determined by multiple criteria including class, race, ethnic identity, personal experience and other factors. It is generally found that interpersonal relationships among the members in the families in the upper and lower class are absolutely weak. Thus search for freedom or perpetual poverty hence search for escapism.

In a press release by the United Nations during a conference on the effects of modernization and industrialization of families submitted that modernization is eroding traditional community support for families in some countries, industrialization in others is driving more women into the labour force, creating new child care challenges for governments, the private sector and non-governmental organizations. According to the conference, traditionally, families took care of the disabled but modernization was eroding that practice, so that now the disabled could be found begging in the streets.

In the meantime, the whole world is in flux of transformation in social structures, cultural values and behavioural patterns due to modernization process. People move around the world, migrate and return, live abroad and raise children abroad. They are bound to live together with other ethnic and cultural groups; the process of modernization has its impacts everywhere and Nigeria was not an exception. (Jiloha, 2009). Modernization has brought contract migration which requires a temporary separation from the family, and living in a culturally ethnically and religiously different environment on the host country. Evidences of stress and strain are becoming increasingly manifest in marital and family relationships. It is noted that the price paid by families was in the form of disruption of family and disorientation of the family setting and that of the social relationship. Cases of break ups in the family as a result of migration or polygamy as a result of separation of married couples are on the increase.

The traditional African family setting is very passionate about the aged as regards the welfare and love. The attitude to provide the aged with the love and care that they deserve are now becoming difficult to fulfil as the search for employment opportunities takes their sons and daughters more to locations away from their homes to distant lands (UN, 1999). In Nigeria, there has been a long tradition of support the senior citizens and the old people including old members of the family, a feature which is prominent and provides economic security for the elderly in the family, particularly in the rural areas. The changing family patterns and size have weakened this security system of the older citizens.

\section{THEORETICAL FRAMEWORK}

\section{MODERNIZATION THEORY}

Modernization theory is a description and explanation of the processes of transformation from traditional or underdeveloped societies to modern societies. Modernization theory has been one of the major perspectives in the sociology of national development and underdevelopment. Primary attention has focused on ways in which past and present pre modern societies become modern through processes of economic growth and change in social, political and cultural structures. Modernization is a multi-faceted phenomenon involving political, economic, social and cultural as well as psychological processes whose cumulative effects are to move a society from traditional or quasi-state to a more developed state.

A lot of propositions have been made by modernization theorists, each theorist emphasising what he feels hamper or would affect the modernization of hitherto traditional society. Tilly (2008) believed that modernization involves the development of an industrial labour force, an educated population, urbanization and political participation with concomitant changes and inevitable interrelation. Black (1972) submitted that that modernization is a process by which historically evolved institutions are adapted to the rapidly changing functions that reflects the unprecedented increase in man's knowledge, permitting control over his environment that accompanied the scientific revolution. Moore (2000) observed that what is involved in modernization is a total transformation of a traditional or premodern society into the type of technology and associated social organization that characterised the advanced economically prosperous and relatively stable nations of the world. 
Neil (1990), a close collaborator of Parsons, similarly conceives modernization as a transition from multifunctional to uni-functional social structures. In pre-modern society, the family is conceived with production and consumption, with basic socialization and further education and in some cases with religious and political activities. With modernization, most of these functions are severed from the family. Production is taken over by separated economic enterprises, a large part of education is vested in formal organizations such as schools, universities, and youth movements, political functions are assumed by national, state and local authorities and religious functions by the church. The family is now left with only consumption and primary socialization as its chief contributions to society. Modernization does not necessary mean that the people may discard all their traditional values or cultural and political heritage. Though their powers have been sufficiently curtailed, yet they have been made useful institutions which could serve the growing needs of the society.

In total, modernization is a progressive process which in the long run is not only inevitable but desirable (Reyes, 2001). According to Coleman, modernized political systems have a higher capacity to deal with the function of national identity, legitimacy, penetration, participation and distribution than the traditional political systems. Modernization is a lengthy process; it is an evolutionary changes not a revolutionary one. It will take generations or even centuries to complete.

Generally speaking, modernization has the following characteristics:

(a)Application of technology and mechanization

(b)Industrialization

(C) Urbanization

(d)Rise in national and per capital income

(e )Increase in literacy

(f)Political participation

(g)development of mass-media

Modernization theory suggests that rapid urban and modernization would result in a nuclear family form supplanting traditional extended families, although extended families are less frequent in the present generation, modern communication and transportation technology has enhanced close family relations among kin, such that the modified extend form of the nuclear family is now more common than the Western nuclear form (Sultan, 1991).

\section{CONCLUSION}

In general, when societies move from agricultural economies to industrialized economies, the extended family is replaced by the nuclear family because large families are no longer needed to supply the necessities of life (Goode, 1970). The overall effect of industrialization/modernization on the family institution can never be under estimated. It has moved the family from the traditional, extended, and closely knitted and production type to a nuclear and consumption type. . The traditional African family which is known to be agrarian, polygamous and extended has underground changes where nuclear and asymmetrical types have emerged; family support for the elderly is affected by the changes in the family formation, family dynamics, as well as people's value and their way of life. High degree of physical mobility associated with new job opportunities at urban centres has loosen the phenomenon of face to face relationships and eroded the strength of the family.

\section{REFERENCES}

Anthony. G (2001) “The Modern Family”. International Journal of Humanities and Sciences. Vol.3 No.5.

Arensberg C.M and Kimball S.T (1968) "Family and Community in Ireland". Harvard University Press. 
Black C.E (1972) “Modernization and Growth”. Oxford University Press. London.

Cao T (2012) "The Impact of Modernization on Family Structure and Function: A Study Among Beijing, Hong Kong and Yunnan Families". Lingnan University Press.

Chaughry. A. (2004) "Rural Sociolgy”. Dominant Publishers and Distribution. New Delhi P.105.

Edwin Shorter (2000) “The Family, Education and Society”. Oxford University Press. Vol.8, No23.

Goode W.J (1963) “The Family”. Macmilliam Publishing Co. Inc.

Ibrahim. S (2004) "Cognition and Impact of Modernization in Changing Normative Structure of Family System". International Journal of Business and Social Science. Vol.2 . No.14.

Jiloha R.C (2009) "Impact of Modernization on Family and Mental Health in South Asia". Delhi Psychiatry Journal. Vol.12. No. 1

Morris. Z (2005) “The Family in a Social Context”. Cambrige University Press.

Perlman. U.T (2008) “The Caring Family”. Journal of Social Sciences and Humanities.

Young. J and Willmott.Y.U (2010) "The Family and Kinship". International Journal of Social Sciences and Humanities. Vol. 9 No.39.

Young. J and Willmott. Y.U (2004) “ Symmetrical Family”. International Journal of Management and Humanities. Vol.5 No.10 45.

Reyes G.E (2001) "Theories of Development: Modernization, Dependency, World-System and Globalization". University of Pittsburgh.

Shorter V.B (2007) “ Making a Good Family”. International Journal of Research and Developmental Growth. Vol.2 PP34-37.

Sultan M.A (1991) “The Effects of Urbanization and Modernization on Family Structure in Oman”. Portland State University.

Tiily. C (2008) “Towards a Modern Society”. International Journal of Sciences and Development”. Vol.7. PP 4450 .

United Nations Press Release. 